\title{
JANA ZE STOBNICY (1470-1519) WYKŁAD O GRECJI. INSPIRACJE ENEASZA SYLWIUSZA PICCOLOMINIEGO (1405-1464)
}

\begin{abstract}
Zawadzki Robert K., Jana ze Stobnicy (1470-1519) wyktad o Grecji. Inspiracje Eneasza Sylwiusza Piccolominiego (1405-1464). (The lecture of Jan of Stobnica (1470-1519) on Greece. Inspirations of Aeneas Silvius Piccolomini (1405-1464)).

The article offers insights on the reception and cultural transmission of one of the most important Renaissance texts entitled De Europa written by Aeneas Silvius Piccolomini, an Italian scholar (he became Pope Pius II in 1458). His work was adopted and adapted by the Polish scholar Jan of Stobnica. In his dissertation Introductio in Ptolemaei cosmographiam cum longitudinibus et latitudinibus regionum et civitatum celebriorum, he took up all issues of Piccolomini 's treatise, including geographical and historical aspects of Greece. His attitude to this material was very positive. The article considers the motifs of Greek districts, such as Macedonia, Thessaly, Boeotia, Attica, the Peloponnese, the Isthmus, Achaea, Acarnania, Epirus, and the significance of Greece for Polish Renaissance culture.
\end{abstract}

Keywords: Renaissance literature; geography; Greece; Polish culture.

Jeśli chcemy poznać wymiar i znaczenie rozważań Jana ze Stobnicy ${ }^{1}$ na temat Grecji, powinniśmy je sytuować na tle nauk geograficznych, jakie wzrastały w Polsce, przede wszystkim w Akademii Krakowskiej na przełomie XV i XVI stulecia ${ }^{2}$, istniały bowiem między nimi ścisłe zależności. Nauki te dzieliły się zasadniczo na dwie dziedziny, pierwsza to badania ziem polskich, których najwspanialszą charakterystykę pozostawił Jan Długosz ${ }^{3}$, nieograniczający się tylko do opisów własnego państwa, lecz ogarniający także tereny sąsiadów i czyniący to w sposób rzetelny, zmierzający do ujęcia całościowego, i - co z tym związane - przedstawienia wszystkiego, co składało się na obraz danego

${ }^{1}$ O Janie ze Stobnicy vide Tarnowska 1962-1964: 480-481; Barycz 1935: 250-252; Michalski 1913: 12-13; Michalski 1915: 21-80; Gniadek 1956; Staszewski 1966: 145-146; Palacz 1970: 23-38.

${ }^{2}$ Niestety nie istnieje osobna monografia na ten temat. Czytelnik ma do dyspozycji świetne opracowanie dotyczące kartografii: Buczek: 1963.

${ }^{3}$ O chorografii Długoszowej vide Szelińska 1980; Szelińska 1984. 
terytorium, więc jego granic, miast, rzek, jezior, gór oraz ludności ${ }^{4}$. Dziedzina druga to wykraczanie poza ziemie polskie i kraje bliskiego sąsiedztwa, zainteresowanie państwami europejskimi, ale także powiązane z pragnieniem poznania innych kontynentów. Tym dwóm dziedzinom dane było jednak nierównomiernie się rozwijać. Najdawniejsi pisarze działający w Polsce przedkładali zdecydowanie sprawy tego kraju nad opisy realiów obecnych u innych narodów. Polska była treścią dzieł Galla Anonima i innych dawnych kronikarzy i historyków, była tym, co mieli do opisania, motorem zaś owego opisywania było przeświadczenie o pierwszeństwie Polski, która jawiła się im jako kraj nadrzędny, ważniejszy niż obce państwa.

Z tego względu w średniowieczu uwagi o krajach dalej położonych są w Polsce bardzo rzadkie i nikłe. Geografia bowiem nie istniała jako osobna dziedzina wiedzy, na którą składać się miały uczone traktaty, posługujące się odrębnym słownictwem i własną metodologią. Pojawiła się dopiero pod koniec XV stulecia ${ }^{5}$. Stanowiła jednak wtedy, w swej początkowej fazie, całkowitą kopię czy może raczej atrapę geografii antycznej. Działo się tak za sprawą Wawrzyńca Korwina (ok. 1465-1527) ${ }^{6}$, autora pierwszego w Polsce dzieła geograficznego pt. Cosmographia dans manuductionem in tabulas Ptolemaei, które, choć wydane w Bazylei w 1496 roku, zawierało wykłady tego uczonego wygłoszone w Akademii Krakowskiej i cieszyło się dużą popularnością wśród studentów i czytelników ${ }^{7}$. Utwór nie ma - co należy podkreślić - charakteru oryginalnego, przeciwnie, w stopniu niemal całkowitym i zupełnym był świadomie przepisany od różnych pisarzy starożytnych, stanowiąc wyraz tego, co dziś nazywa się imitacją i plagiatem, i wiązał się z dążeniem do ukazania osiągnięć geografii antycznej, która w Polsce nie była jeszcze znana. Chodziło o szybkie zaprezentowanie wizji świata, jaką posiadali starożytni. Dążenie to miało oczywiście, nawet już wtedy, czyli w końcu XV wieku, charakter anachroniczny - nie tylko $\mathrm{w}$ wymiarze naukowym, także $\mathrm{w}$ tym sensie, że zmierzało do narzucenia poglądu o niezmienności geografii, która nie powinna wykraczać poza paradygmaty nakreślone przez pisarzy greckich i rzymskich. Nie ulega wątpliwości, że takie podejście do dyscypliny, której istotną cechą jest rozwój, skazałoby ją na zastój - w każdym razie nie przystawało w ogóle do ówczesnych czasów, naznaczonych wielkimi odkryciami zamorskimi. Nic dziwnego, że dzieło Korwina, choć pionierskie w Polsce, uległo szybko zapomnieniu nie pociągając za sobą kontynuatorów i epigonów.

Anachronizm utworu Korwina był paradoksalnie jednym z ważnych czynników rozwoju geografii przez innych badaczy w Akademii Krakowskiej. Na

\footnotetext{
${ }^{4}$ Vide Michałowska 1997: 771-772.

${ }^{5}$ Iłowiecki 1981: 31. O rozwoju nauki polskiej w renesansie vide Skubała-Tokarska 1983: 41-55; Wielgus 2005: 104-107; Knoll 2016: 373-402.

${ }^{6}$ O Korwinie vide Barycz 1935; Barycz 1948: 499-562; Rott 1995.

${ }^{7}$ O Kosmografii vide Zawadzki 2013: 96-122.
} 
pewno proces ten nie ustał na początku XVI stulecia, choć niewątpliwie przybrał inną od Korwinowej postać. Geografia nie była już i nie mogła być bierną odtwórczynią starożytnej wiedzy o świecie - także z racji oczekiwań, postulatów i wymagań tych, którzy odbywali podróże do dalekich krajów. Geografia miała ukazywać ówczesne realia, co oznaczało, że musiała się wyrzec wizji prezentowanych przez starożytnych pisarzy - a przynajmniej znacznie je ograniczyć bądź zweryfikować, ale też, że musiała uwzględnić nowoodkryte ziemie oraz na co czekali żądni sensacji czytelnicy - je opisać.

Zadania te, wynikające $\mathrm{z}$ ducha czasów i potrzeb czytelników, realizował w swej działalności i twórczości Jan ze Stobnicy, prawdopodobnie kolega Wawrzyńca Korwina ze studenckiej ławy, później zaś profesor Akademii Krakowskiej. Realizował przede wszystkim w swoim największym dziele kosmologicznym Introductio in Ptolemaei cosmographiam cum longitudinibus et latitudinibus regionum et civitatum celebriorum. Część astronomiczna tego utworu wydanego po raz pierwszy w 1512 roku$^{8}$, a więc w epoce przedkopernikańskiej, nie mogła oczywiście w sposób właściwy przedstawić struktury kosmosu. A działo się tak dlatego, że opierała się ona całkowicie na geocentrycznych koncepcjach Klaudiusza Ptolemeusza, choćby takich, które głosiły tezę, że Ziemia znajduje się w samym środku wszechświata. O wiele ciekawsza i bardziej nowatorska jest część geograficzna dysertacji. Jan ze Stobnicy starał się tu ukazać obraz ówczesnego świata. Wiedział on już, że ów świat jest kategorią specyficzną i zarazem tak trudną do ogarnięcia, bo w jego przedstawieniu przestały obowiązywać te reguły, które charakteryzowały relacje antyczne, ale także tradycyjne, starożytne wyobrażenia na jego temat. Krakowski uczony w sposób niebudzący wątpliwości chciał uwzględnić ówczesne realia, jednak w relację o nich włączył informacje, które absolutnie nie były jego własnością intelektualną, bo pochodziły od innych pisarzy. Postępował zatem podobnie jak Korwin z tą tylko różnicą, że jego starszy kolega kopiował autorów antycznych, on zaś czynił tak w odniesieniu do pisarzy nowożytnych. Ten sposób postępowania, dzisiaj raczej nie do przyjęcia, daje się w pewnym sensie zrozumieć i usprawiedliwić, gdyż w tamtej epoce w ogóle był charakterystyczny dla działalności naukowców, zwłaszcza tych, którzy pozbawieni byli tzw. zaplecza badawczego w postaci choćby środków finansowych umożliwiających im dokonywanie wypraw do obcych krajów. Jan ze Stobnicy nie odbywał podróży ani po Europie,

\footnotetext{
${ }^{8}$ Wydanie to ukazało się w Krakowie w oficynie wydawniczej Floriana Unglera. Wydanie drugie ujrzało światło dzienne w 1517 roku również w Krakowie w wydawnictwie Hieronima Wietora. W niniejszym szkicu korzystam z obu tych wydań (Edycja z 1512 r.: PAN Biblioteka Kórnicka Cim. Qu.2009, Cim. Qu. 2010. Edycja z 1517 r.: PAN Biblioteka Kórnicka Cim. Qu. 2134), które w zasadzie niczym istotnym się nie różnią. Różnice dotyczą pojedynczych wyrazów, np. na określenie terminu „kaplica” w edycji z 1512 roku pojawia się określenie: capella, zaś w edycji z 1517 bardziej poprawne sacellum. Wydanie z 1517 roku posiada ponadto bardziej wyrazistą czcionkę ułatwiającą lekturę.
} 
ani po innych kontynentach, mieszkając w Krakowie nie prowadził własnych poszukiwań i ekspedycji, cała jego wiedza o tych krajach pochodziła z książek, jakie miał u siebie.

Przystąpił więc do opisywania świata w sposób podobny jak jego poprzednik, sięgnął jednak - jak się rzekło - do źródeł najnowszych, opierając się na autorach sobie współczesnych lub tylko trochę od siebie starszych, przedstawiał zatem teksty w połowie i pod koniec czy na początku XVI wieku powstałe, wielorako do tych czasów się odnoszące i jak najbardziej wtedy aktualne. Postępowanie jego odznacza się więc w świetle pisarstwa Korwina pewnym nowatorstwem, polegającym właśnie na wykorzystywaniu najnowszych źródeł literackich. Przywoływanie autorów współczesnych, operowanie na ich tekstach, wzmianki o najnowszych odkryciach geograficznych dawały efekt naukowo ciekawy i skuteczny, eliminując w dużej mierze z polskich nauk geograficznych ten archaizm, jaki sprowadziłoby nieuchronnie posługiwanie się wyłącznie ustaleniami Strabona i Ptolemeusza.

Jednym z autorów, których teksty Jan ze Stobnicy cytował, był Eneasz Sylwiusz Piccolomini (1405-1464) ${ }^{9}$. Nie trzeba przypominać, że człowiek ten należał do głównych postaci humanizmu włoskiego i europejskiego. Zdobył sławę nie tylko jako papież Pius II (od roku 1458), ale także jako literat i naukowiec. Zajmował się m.in. geografią. Stała się ona dla niego ważna nie tylko jako dziedzina wiedzy badająca zewnętrzne zróżnicowanie ziemskiej powłoki, łączyła się także ściśle z historią współczesną. U niego granica między fizycznym opisem danego miejsca a tym, co w tym miejscu się wydarzyło, zacierała się, sfera wypadków dziejowych wchodziła w opis geograficzny, była przedmiotem refleksji, nieuznającej odrębności tych dwóch dyscyplin, znoszącej podziały na wypowiedzi chorograficzne i historyczne. Żył Europą i jej sprawami, traktował ją jako jedność kulturową i religijną, uznając równocześnie odrębność poszczególnych narodów. Z Europą wiązała się jego idea walki, idea obrony kontynentu przed imperializmem tureckim, który uważał za największe zagrożenie. Te postawy i myśli ujawniały się w jego jednym z najbardziej znaczących dzieł: De Europa, które wywarło wpływ na styl pisania wielu renesansowych autorów o Europie, a w konsekwencji na sposobie postrzegania kontynentu przez ludzi tego pokolenia i następnych generacji. Utwór zdobył wielką popularność, cechowała go erudycja, tak w wymiarze źródeł pisanych, jak i osobistych doświadczeń autora jako naukowca, podróżnika i dyplomaty. Były to ważne czynniki decydujące o walorach dzieła. Jeśli więc chodzi o materiały będące podstawą wiedzy w nim przekazywanej, Piccolomini korzystał tak z własnych obserwacji, przeżyć, znajomości, jak i z olbrzymiej ilości tekstów pochodzących z czasów starożytnych, średniowiecznych i sobie współczesnych.

${ }^{9}$ O życiu i twórczości Piccolominiego vide Ojrzyński 2014, tutaj też bogata bibliografia. Vide Bisaha 2013: 3-45. 
Jan ze Stobnicy stał się entuzjastą dysertacji Piccolominiego ${ }^{10}$. Doceniał jej nowatorstwo, świeżość, aktualność, chciał ją wiernie przytoczyć, nie mógł jednak tego uczynić w całości z różnych względów, postanowił zatem cytować obszerne fragmenty, rezygnując z tych ustępów, które wydawały się mu mało ciekawe dla polskiego czytelnika ${ }^{11}$. Wypowiedzi Piccolominiego dołączył zatem do swojej dysertacji Introductio in Ptolemaei cosmographiam, dobitnie przyznając ich autorstwo włoskiemu duchownemu i podkreślając skrótowy charakter zamieszczonego tekstu, będącego tylko wyciągiem z obszernego oryginału: Epitoma Europae Aeneae Silvii. W ten sposób znalazły się w utworze Jana ze Stobnicy informacje o wszystkich ówczesnych państwach europejskich (również o Polsce), wiadomości historyczne, rozważania polityczne, filozoficzne, religijne; słowem, prawie wszystko to, o czym, traktował pisarz z Italii. Nie zabrakło też kilkustronicowego passusu dotyczącego Grecji, a w zasadzie poszczególnych regionów historycznych składających się na ten kraj; wszak podział na liczne poleis - jak wiadomo - odegrał w dziejach starożytnej Hellady ogromną rolę.

Grecję opisano konsekwentnie, według kryterium geograficznego, rozpoczynając od terenów położonych na północy, a na południowych kończąc. Merytoryczna wiedza, ekonomia słowa, reminiscencje historyczne - wszystko to pasuje doskonale do przedstawionej koncepcji dzieła. Przegląd greckich krain zaczęto zatem od Macedonii, bo ona stanowiła najbardziej na północ wysuniętą grecką dzielnicę [38]:

Proxima Thraciae ad occidentem ac meridiem coniungitur Macedonia, terrarum imperio quondam [39] potita, quae inter duo maria protenditur - Aegeum et Adriaticum, latus eius meridionale Thessaliae atque Magnesiae terga protegunt, partem septentrionalem Paeonia et Paphlagonia ${ }^{12}$ excipit, quamvis et ipsae regiones in Macedonum postea iura concesserint Macedoniae additae. Epirus quoque Macedoniam attigit et Illyrica terra ${ }^{13}$, altera meridiem, septentrionem altera excipiens.

Graniczy z Tracją od zachodu i południa Macedonia, stanowiąca niegdyś mocarstwo [39] terytorialne. Rozciąga się ona między dwoma morzami: Egejskim i Adriatyckim. Jej granica południowa dotyka terenów Tesalii i Magnezji, północna opiera się o ziemie Peonii i Paflagonii, choć i te kraje podległe były niegdyś prawom macedońskim - należały do Macedonii. Z Macedonią graniczy Epir oraz kraj iliryjski; ten pierwszy sąsiaduje z Macedonią od południa, ten drugi od północy ${ }^{14}$.

${ }^{10}$ Dzieła Piccolominiego znane już były Janowi Długoszowi. Vide Michałowska 1997: 774. Niewykluczone, że znajdowały się w bibliotece Akademii Krakowskiej. Potrzebny egzemplarz mógł mieć Jan ze Stobnicy właśnie stamtąd, mógł także wypożyczyć od jakiegoś kolegi; „krążenie książek" było wówczas bardzo modne.

${ }^{11}$ Nie sposób ustalić jednej zasady, którą kierował się Jan ze Stobnicy dobierając takie a nie inne cytaty z dzieła Piccolominiego. Wydaje się, że istotne było tu kryterium subiektywne. W każdym razie rzecz wymaga przebadania w osobnym studium.

${ }^{12} \mathrm{Cf}$. Plinius, Historia Naturalis 4, 33.

${ }^{13}$ Illyrica terra - prawdopodobnie chodzi o dzisiejszą Bośnię.

${ }^{14}$ Wszystkie cytaty w thumaczeniu Roberta K. Zawadzkiego. 
Ustęp ten wpisuje się oczywiście doskonale w ideę utworu. Dzieje się tak dlatego, że opis Macedonii nie ogranicza się tylko do przedstawienia jej wszystkich granic, dotyczy także dawnych dziejów i przez to owa sławna wielkość tego państwa staje się jednoznaczna, wymowa jej jest bezsporna. Fakt wspomniany w tej relacji odnosi się do najsławniejszego wycinka historii Macedonii, jego przywołanie już w pierwszym zdaniu sprawia, że ową potęgę militarną czytelnik od razu z dawną Macedonią identyfikuje. W rezultacie pokazuje się, że opowieść pod względem geograficznym bezbłędna, ubogaca się jeszcze o znaczącą treść historyczną.

Wyrazem splatania kwestii geograficznych z historycznymi, wyrazem przeświadczenia, że opis danego miejsca powinien uwzględniać sławne zdarzenia z nim związane, jest także relacja o terenach położonych na południowy zachód od Macedonii, w kierunku Morza Adriatyckiego [39]:

In Adriatico litore Dyrrachium vetus civitas iacet, ab Cheroneso, ubi sita est, nacta vocabulum, Epidamnus antea dicta et a Corciris olim condita. Nec procul infra terram Apollonia fuit optimis instituta legibus et Augusti Caesaris, qui Graecas ibi litteras didicit, studio memorabilis.

Na wybrzeżu adriatyckim leży starożytne miasto Dyrrachium. Swoją nazwę zyskało od półwyspu, na którym się znajdowało, wcześniej określano je mianem Epidamnus, zostało założone przez przybyszów z wyspy Korkyry. Niedaleko tych ziem, tylko nieco niżej, znajduje się Apollonia, miasto rządzące się świetnymi prawami, sławne z tego, że tutaj wychował się i poznawał literaturę grecką cesarz August.

Konkretne informacje rejestrujące dane geograficzne, detale onomastyczne i wątki anegdotyczne mają tu charakter przekazu właściwego dla przewodnika turystycznego - przekazują merytoryczne wiadomości, wzmiankują o szczególnych, znamiennych faktach, zwłaszcza relacja o Apollonii budzi zaciekawienie; dzieje się to oczywiście nie z powodu jakichś specjalnych względów geograficznych, lecz w wyniku przywołania postaci cesarza Augusta, związanego za młodu $\mathrm{z}$ tym miastem. Osoba wielkiego władcy pobierającego nauki o literaturze greckiej w nadmorskim kurorcie zwiększa atrakcyjność tego miejsca, wzmaga u czytelnika pragnienie głębszego poznania i odwiedzenia tych terenów, zwłaszcza, że Apollonia nie była jedynym magnesem mogącym przyciągnąć potencjalnych turystów. Również w północnej Grecji, lecz z drugiej strony Macedonii, a więc nad Zatoką Termajską leżało miasto sławne działalnością innej ważnej osoby [39]:

In altero litore Thessalonica est, potens quondam civitas, quam epistulae Pauli apostoli famosam reddidere. (...) Hanc simulac Magnesiam nostro tempore Turcorum arma invaserunt.

Na przeciwległym wybrzeżu leży Tesalonika, potężna niegdyś metropolia, którą rozsławiły listy apostoła Pawła. (...) Również i na to miasto, podobnie jak i na Magnezję, w naszych czasach najechały wojska tureckie. 
Trzon tej wypowiedzi niezależnie od jej geograficznego i współczesnego kontekstu, był bardzo dobrze zrozumiały dla każdego chrześcijanina. Trzonem tym jest myśl, że Tesalonika pozostaje miejscem bliskim i drogim, bo wiąże się $\mathrm{z}$ apostołem Pawłem - autorem bardzo znanych Listów, czytanych w kościołach podczas mszy świętych. Myśl słuszna i wspólna obu odłamom chrześcijaństwa, a jednak konkluzja jej w świetle aktualnych wydarzeń okazywała się smutna i żałosna - muzułmańscy Turcy wydarli miasto wyznawcom Chrystusa.

Motyw podbojów tureckich, zajmowania przez muzułmanów terenów naznaczonych kulturą chrześcijańską i antyczną, będzie się przewijać - jak zaznaczyliśmy - przez cały utwór. Oprócz tej jednej wzmianki o zaborczości islamistów pojawia się w dziele sporo innych, rozmaitej wielkości i tematyce, ale zawsze mniej lub bardziej przenikniętych jakąś nostalgią i żalem, że terytoria stanowiące ważną część cywilizacji europejskiej dostają się w ręce pogan. Tak dzieje się, gdy padają uwagi odnoszące się do gór i rzek rozsławionych przez antycznych poetów i prozaików [39]:

Nobilissimi montes Olympus, Pieris et Ossa, Pindus insuper et Othrys ${ }^{15}$ Lapitharum quondam sedes Turcorum imperio parent, penes quos quinque et LXX urbes fuisse olim Plinius affirmat ${ }^{16}$. Totum Peneum Turci possident ${ }^{17}$ inter flumina Thessaliae clarissimum.

Także bardzo sławne góry: Olimp, Pieris, Ossa, Pindus, a ponadto i Othrys - dawna siedziba Lapitów, znajdują się pod tureckim panowaniem. Do owych zaś Lapitów należało, według Pliniusza, siedemdziesiąt pięć miast. Cały bieg rzeki Penejos, która jest najsławniejsza wśród rzek Tesalii, posiadają Turcy.

Oczywiście, nie ma w tym ustępie żalu wyrażonego expressis verbis, niemniej pewien rodzaj smutku jest wyczuwalny. Rzecz bowiem w tym, że poprzez wizję Turków zagarniających miejsca bardzo ważne, cenne, opisywane w samych superlatywach (nobilissimi montes, clarissimum flumen) została wypowiedziana teza bardzo czytelna, uczuciowo intensywna, manifestująca właśnie jakby rozgoryczenia z powodu utraty tych ziem.

Należy jeszcze raz powtórzyć, że czyste, pozbawione autorskiego komentarza konstatacje geograficzne nie zawsze są obecne w utworze. Niekiedy pisarz formułuje wyraźną konkluzję, wyraża własne sądy. Dzieje się tak w opisie Tesalii, w której znajdował się sławny wąwóz termopilski [39]:

Homerus tribus nominibus Thessalos appellavit, Myrmidonas, Helenos et Acheos ${ }^{18}$. Hic Thermopilarum angustiae, Persarum caede insignes ${ }^{19}$. Quae licet Xerxis impetum tenuere, Tur-

\footnotetext{
${ }^{15}$ Othrys corr.: Othys - chodzi o góry w Tesalii.

${ }^{16}$ Plinius, Historia Naturalis 4, 15, 30.

${ }^{17}$ Sułtan Mehmed II podbił w 1458 roku Macedonię, Tesalię, Trację.

${ }^{18}$ Homerus, Ilias 2, 684.

${ }^{19}$ Chodzi o sławną bitwę stoczoną w roku 480 przed $\mathrm{Chr}$.
} 
corum tamen armis claudere transitum minime potuere, quamvis nostram magis desidiam accusandam putaverim.

Homer trzema nazwami określa mieszkańców Tesalii, nazywa ich mianowicie Myrmidonami, Helenami i Achajami. Tutaj w Tesalii leży wąwóz termopilski, rozsławiony rzezią Persów. Choć powstrzymał atak Kserksesa, jednak już nie był w stanie zamknąć drogę przejścia wojsku tureckiemu. Niemniej uważam, że winą za powodzenia Turków należy raczej obarczyć naszą bezczynność.

Nad przedstawionymi w tej relacji zdarzeniami ciąży najwyraźniej jedna okoliczność - bezczynność Europejczyków wobec tureckich podbojów. Jest to fakt wszystko właściwie tłumaczący - sukcesy islamistów, reakcje mieszkańców Europy na bieżące sprawy w skali całego kontynentu, zagrożonego niebezpieczeństwem inwazji obcych. Fakt europejskiej obojętności stanowi przeciwieństwo postępowania starożytnych Greków, których symbolem walki do końca były Termopile. Na tym właśnie polega zarówno erudycja pisarza, jak i jego przenikliwość, że chciał czytelnikowi pokazać za pomocą wypadków historycznych, jak ważną sprawą jest wspólne, zdecydowane działanie wobec zła. Termopile - dawny symbol męstwa i walki stały się znakiem klęski, który pisarz stawia przed czytelnikiem, gdyż całe to zdarzenie przepuszczenia Turków było bez reszty antytezą tamtego odległego i chwalebnego czynu.

Cytowany fragment zaciekawia z jeszcze innego względu. Przed motywem Termopil pojawia się nuta literacka - wspomnienie Homera, z którym wiążą się trzy dawne nazwy mieszkańców Tesalii. Nie można chyba tego napomknięcia określić mianem dopisku czy zwykłej ciekawostki. Czujemy dobrze, że jest tu coś więcej, to reminiscencje antycznego przeświadczenia o autorytecie Homera, przekonanie, że autor Iliady jest arbitrem w dziedzinie nazw, określeń i pojęć.

Podobny, „literacki” charakter ma następny passus. Mowa w nim o krainie zasobnej w źródła i strumyki dające poetom natchnienie. Kraina ta wydała wielu wybitnych mężów, równać się mogła sławą samym Atenom [39]:

Post Thessaliam Boeotia succedit ab ortu in occasum porrecta, Euboicum mare, Criseum sinum $^{20}$ contingens, Thebarum claritate apud omnes ferme historicos nominata, hic Musis natale in Heliconis nemore, hic saltus Cytheron et Hysmenus amnis et fontes Dirce, Arethusa et Aganyppe. Quae patria quondam Liberi patris atque Herculis fuit, quae fortem produxit Epaminondam $^{21}$, non cedens Athenis claritate civitas. Ea nostra aetate exiguum castellum Thebarum est, et a Turcis proximis annis cum reliqua Boeotia occupatum.

Za Tesalią zaczyna się Beocja, rozciągająca się wszerz od wschodu do zachodu, dotykająca Morza Eubejskiego i Zatoki Kryzejskiej, znana u prawie wszystkich historyków przede wszystkim ze sławnych Teb, tutaj w helikońskim lesie przyszły na świat Muzy, tutaj znajduje się wąwóz cyteroński, płynie rzeka Hysmenus, tryskają źródła Dirce, Arethusa i Aganyppe.

\footnotetext{
${ }^{20}$ Criseus sinus - nazwa pochodzi od miasta Crisa w Fokidzie, leżącego u stóp Parnasu.

${ }^{21}$ Epaminondas - sławny wódz Tebańczyków, zwyciężył Spartan w dwóch bitwach.
} 
Była to niegdyś ojczyzna Dionizosa i Herkulesa, ona to zrodziła dzielnego Epaminondasa, nie ustępowała w sławie Atenom. W naszych czasach zmniejszyła się do warowni tebańskiej, podbitej zresztą w ostatnich latach przez Turków wraz z całą Beocją.

Przedstawiony ustęp jest jakby rzutem oka na całą Beocję, podsumowaniem kwestii geograficznych, literackich, mitologicznych i historycznych związanych $\mathrm{z}$ tą krainą. Razem tworzą one spójną całość. Czymże bowiem, jak nie podsumowaniem losów Beocji są ostatnie słowa kończące akapit, mówiące o niej, że „W naszych czasach zmniejszyła się do warowni tebańskiej, podbitej zresztą w poprzednich latach przez Turków wraz z całą Beocją"? Ukazuje to jednocześnie czytelnikowi wspaniałe dzieje ojczyzny Muz, naznaczone wielkimi dziełami i postaciami. One to sprawiły, że mimo żałosnego, ówczesnego stanu tej krainy, nie można było nie zauważyć jej osiągnięć. Osiągnięcia nie zaginęły bowiem, trwały nadal, o czym mogła zaświadczyć nie tylko cytowana wypowiedź, ale w zasadzie cała literatura europejska, posługująca się niejednokrotnie motywami wyrosłymi na beockiej ziemi.

Dzięki utworowi Piccolominiego i przywołaniu tego dzieła w dysertacji Jana ze Stobnicy wiemy, jak wizja Beocji prezentowała się w literaturze renesansowej i co znaczyła. Poznajemy także wyobrażenie innej krainy, dla której w książce przedstawiającej opis Europy miejsca nie mogło zabraknąć. Oczywiście, kraina ta nosiła w sobie swoje własne cechy, wyróżniały ją one spośród innych krain, stanowiły przede wszystkim symbol i kwintesencję całej Grecji [39]:

Sequitur Hellas, quae a nostris Graecia appellata: Acten, id est, litus prisci vocavere. Mutato deinde nomine Atticam dixere ${ }^{22}$. Homerus cunctos Atticam incolentes appellavit Athenienses. [...] Protenditur autem Attica ex Boeotia usque in Isthmum Corinthiacum, parte sui quae appellatur Megaris. [...] In Attica civitas Atheniensis quondam nobilissima, nostro tempore parvi oppidi speciem gerit. In eo tamen saxo, quo vetustum Minervae templum ${ }^{23}$ fuit, Arx est per omnem Graeciam nominata, cum operis magnitudine, tum ${ }^{24}$ difficultate oppugnationis, hanc Florentinus quidam Machometi tradidit ${ }^{25}$, cum imploratis Latinorum auxiliis nullius opem inveniret.

A teraz opowiemy o Helladzie, którą nazywamy Grecją. W dawnych czasach mówiono $A c-$ ten, to znaczy wybrzeże. Nazwa ta następnie uległa zmianie i zaczęto mówić Attyka. Homer wszystkich mieszkańców Attyki nazywa Ateńczykami. [...] Ciągnie się zatem Attyka od Beocji aż do Przesmyku Korynckiego, gdzie graniczy z krainą, która nazywa się Megaris. [...] W Attyce znajduje się miasto Ateny, niegdyś bardzo wspaniałe, w naszych czasach posiada wygląd małej miejscowości. Niemniej na tej skale, gdzie znajdowała się starożytna świątynia Minerwy, wznosi się warownia sławna w całej Grecji, tak ze względu na swoje piękno

\footnotetext{
${ }^{22}$ Strabo 9, 1, 6 .

${ }^{23}$ templum Minervae - chodzi oczywiście o świątynię Ateny - Parthenon.

${ }^{24}$ tum corr.: cum.

${ }^{25}$ Chodzi o wydarzenie z czerwca 1458, kiedy ostatni dowódca załogi broniącej Ateny - Florentczyk Franco Acciaivoli poddał miasto sułtanowi Mehmedowi II.
} 
i ogrom, jak i charakter obronny. Pewien Florentczyk wydał ją sułtanowi, gdy nie doczekał się pomocy od łacinników, choć o nią prosił.

Attyka zrównana tu została z samą Grecją. Nie ulega wątpliwości, że w cytowanym fragmencie mamy do czynienia z właściwą Helladą, której opis dopiero w tym miejscu się zaczyna. I inaczej dziać się nie mogło, skoro w krainie, o której mowa, leżą Ateny (civitas Atheniensis), „niegdyś bardzo wspaniałe” (quondam nobilissima). Jednakże w prezentowanym ustępie utożsamienie Aten z całą Grecją nabiera jeszcze jednego znaczenia: było utożsamieniem miasta z warownią „sławną w całej Grecji” - Partenonem, w którym wznosiła się świątynia Minerwy. Niemniej, jak już wielokrotnie stwierdzaliśmy, teraźniejszość, nieustanny przedmiot odniesień autora, odciska swoje ponure piętno na obrazie wspaniałej Hellady. Bezczynność Europejczyków przybiera tutaj konkretny wymiar. By obronić Grecję przed Turkami, trzeba było przyjść jej z pomocą militarną, przede wszystkim trzeba było wspomóc owego Florentczyka kierującego obroną Partenonu. Upadek Hellady traktowany więc jest znowu parenetycznie, przede wszystkim jako zjawisko, które powinno służyć za przestrogę. Aktualne wydarzenia wprowadzone zostały - by tak powiedzieć - w system geografii.

Przy założeniu, że obraz Hellady do samej Attyki się nie ogranicza, to w prezentowanym wykładzie o Grecji brakuje jeszcze Peloponezu. Oczywiście i ta kraina nie została pominięta, znalazła swoje omówienie w kolejnej części owego zestawienia historycznych regionów Grecji [39]-[40]:

Peloponesus Atticae iungitur ${ }^{26}$, totius Graeciae arx quondam dicta. Nam praeter habitantium in ea gentium nobilitatem atque potentiam, ipse locorum situs principatum designat et imperium. (...) Formam eius platani folio simillimam prisci dixere, longitudine et latitudine ferme $^{27}$ parem. Ab occasu in ortum stadiorum mille CCCC perimetros sive ambitus omissis sinibus, ut Polybio placet, stadia 4000 continet. Arthemidorus 400 superaddit, cui et Plinius ${ }^{28}$ consentire videtur. Idem duo maria terram ambire dicit, Ionium [40] ab occidente et Aegeum ab oriente, angustiae, quibus coniungitur continenti Achaiae, Isthmos appellantur, quinque milia passuum continentes. (...) Hic Corinthus nobilis Colonia fuit. Graeci principes postquam Turcorum potentia in Europam penetravit, ex mari ad mare producto per angustias muro Peloponnesum a reliqua Graecia distinxerunt. Murum Examilium ${ }^{29}$ appellavere. Hanc provinciam Latini hodie Moream vocant. In ea Achaia continetur, Messenia, Laconia, Argos et Arcadia, quae medium paeninsulae obtinet. Amurates ${ }^{30}$ expugnata Thessalonica, subacta Boeotia et Attica, ad Examilium usque profectus perterritis Graecis diruit Murum ${ }^{31}$,

\footnotetext{
${ }^{26}$ Sc. Strabo 8, 1. 3-8. 2. 1.

${ }^{27}$ ferme corr.: forme.

${ }^{28}$ Plinius, Historia Naturalis 4, 9.

${ }^{29}$ Murus Examilius sc. Hexamilion - chodzi o mur obronny, który w roku 1415 wzniósł cesarz bizantyjski Manuel II Paleologos.

${ }^{30}$ Amurates sc. Murad - sułtan turecki.

${ }^{31}$ Pierwsze zniszczenie Muru dokonało się w roku 1423. Piccolomoni mówi tutaj o drugim zniszczeniu, które nastąpiło w 1431 roku.
} 
tributumque annuum dedentibus se Peloponnensibus imperavit. (...) Peloponnesus itaque tota Turcorum imperio adiecta.

Peloponez przylega do Attyki, niegdyś określano go mianem warowni całej Grecji, gdyż pomijając fakt, że mieszkające na nim narody odznaczały się szlachetnością i potęgą, samo położenie tej krainy predestynowało ją do pełnienia roli przywódczej i zwierzchniej. (...) Jej kształt, według dawnych pisarzy, przypomina bardzo zarys liścia platanu, długość i szerokość ma Peloponez prawie takie same. Odległość ze wschodu na zachód wynosi tysiąc czterysta stadiów, obwód, czyli linia okalająca półwysep, według Polibiusza, to wartość 4000 stadiów, nie wliczając w to morskich zatok. Artemidor dodaje do tego jeszcze 400 stadiów, z czym i Pliniusz zdaje się zgadzać. Ten sam autor podaje, że peloponeski ląd oblewają dwa morza, Jońskie [40] od zachodu i Egejskie od wschodu. Półwysep posiada przesmyk łączący go z leżącą na kontynencie Achają, zwany Istmem. Liczy on sobie pięć tysięcy kroków długości. (...). Leżał tutaj Korynt - sławne miasto. Po tym jak potęga turecka wlała się do Europy, greccy dowódcy wznieśli mur przecinający ów przesmyk od morza do morza i oddzielający Peloponez od pozostałej Grecji. Mur nazwali Examilius. Dzisiaj łacinnicy Peloponez określają mianem Morei. Znajduje się na nim Achaja, Mesenia,, Lakonia, Argos i Arkadia, która leży w środkowej części półwyspu. Amurates zdobywszy Tesalonikę, podporządkowawszy sobie Beocję i Attykę, skierował swoje siły na mur eksamilijski, wzbudzając popłoch wśród Greków, zburzył budowlę, a gdy Peloponezyjczycy poddali się, nałożył na nich daninę. (...) Cały zatem Peloponez dostał się pod władzę Turków.

Idea wplatania wypadków historycznych w dyskurs geograficzny, czasem równająca się idei parenetyki, wyraża się w pełni również i tutaj. Ten typ pisania, wychwytującego ważne wypadki dziejowe i wydobywającego bezbłędnie istotne momenty historii ma w sobie coś z kroniki. Oto budowa muru eksamilijskiego przez Greków, następuje atak turecki na ich ojczyznę, podbój Tesaloniki, Beocji i Attyki - w przytoczonym opisie mamy wszystko, co potrzebne do ukonstytuowania pełnowymiarowego widzenia ówczesnej rzeczywistości, wzbogaconego ponadto o bazujący na autorach antycznych ekskurs chorograficzny zawierający informacje o położeniu i wymiarach półwyspu. W rezultacie czytelnik otrzymuje obraz o dużej precyzji, wyposażony w walory poznawcze odnoszące się od razu do kilku dziedzin czy dyscyplin naukowych równocześnie.

Nie zawsze jednak autor posiadał takie wiarygodne i sprawdzone informacje. Niektórych kwestii sam do końca nie potrafił rozstrzygnąć, co wynikało zapewne z faktu, że pewnych regionów Grecji nigdy nie odwiedził. Wówczas miejsce niedwuznacznych ustaleń wynikłych z autopsji czy konkretnych dowodów zajmują wizje wyrosłe na stwierdzeniach antycznych pisarzy. Żywy pozostawał na przykład problem krain sąsiadujących z Peloponezem, żywy pozostawał dylemat lokalizowania śródlądowych miejscowości półwyspu, a autor dzieła zamiast o jednoznacznych danych geograficznych skłonny był mówić o tym, co na ten temat wypowiedzieli Strabon, Ptolemeusz i Pliniusz. Ta antyczna wizja Peloponezu prowadzić mogła w różnych kierunkach, mogła sankcjonować starożytny stan wiedzy, mogła też stanowić wyzwanie, by tę dawną wizję weryfikować i odrzucać [40]: 
Egredienti Peloponnesum per angustias Isthmi ad reliquam Graeciam Strabo ${ }^{32}$ et Plinius $^{33}$ occurrere Atticam tradunt, Ptolemaeus ${ }^{34}$ Achaiam, cuius fines hoc modo describit, ab occasu Epirum, a septentrione Macedoniam et partem Aegei pelagi collocat, ad orientem eiusdem maris terminos ponit usque ad Sunium promontorium, ad meridiem Adriaticum pelagus iuxta litus, quod Achelous amnis irrumpit in Corinthiaco sinu. Quod si ita est, Atticam, Boeotiam, Phocidem, Thessaliam, Magnesiam, Aetholiam et Acarnaniam Achaia ipsa complectitur. Idem tamen Ptolemaeus ${ }^{35}$ alio loco mediterraneas Peloponnesi civitates enumerans, Elicem, Buram, Helenam, Pheream in Achaia esse dicit et propriam esse Achaiam intra Peloponnesum affirmat.

Według Strabona i Pliniusza, ktoś, kto opuszcza Peloponez przez przesmyk istmijski, zmierzając do innych greckich krain, napotyka Attykę. Według Ptolemeusza, jest to Achaja, której granice uczony opisuje w ten sposób. Od zachodu sąsiaduje Achaja z Epirem, od północy z Macedonią i częścią Morza Egejskiego, począwszy od jego wybrzeży sięga na wschód aż do przylądka Sunion, południową granicę stanowią wybrzeża Morza Adriatyckiego, do którego przez Zatokę Koryncką, wpływa rzeka Achelous. Gdyby rzeczywiście tak było, w skład Achai wschodziłyby: Attyka, Beocja, Fokida, Tesalia, Magnezja, Etolia i Akarnania. Niemniej ten sam Ptolemeusz w innym miejscu wyliczając śródlądowe miasta Peloponezu powiada, że takie miejscowości, jak Elis, Bura, Helena, Ferea leżą w Achai. Uczony twierdzi ponadto, że właściwa Achaja znajduje się na Peloponezie.

Renesansowy autor nie zajął żadnego stanowiska wobec ustaleń antycznych pisarzy, rzecz pozostawił nierozstrzygniętą, dlatego jego czytelnicy byli przekonani, że rzeczywistość jest skomplikowana, więc i wiedza o niej nie może być prosta - może być przedmiotem badań i poszukiwań, toteż ma wiele wspólnego z postawą wyzwania - jest w istocie obszarem nowych odkryć.

Autor o szerokich zainteresowaniach geograficzno-historycznych, chcąc dać pełny obraz sytuacji ówczesnej Europy, rezygnował jednak zazwyczaj z tego hipotetycznego języka nierozwiązującego do końca kwestii badawczych. Częściej, oczywiście, posługiwał się, jak się już wielokrotnie przekonywaliśmy, czymś w rodzaju jednoznacznych stwierdzeń naukowych, które wykluczały wątpliwości i miały za zadanie przekazywać obiektywną wiedzę. Aby przedstawić następna grecką krainę - Akarnanię, zastosował wywód bardzo charakterystyczny - będą nim rzeczowe uwagi odnoszące się do położenia tej ziemi stanowiącej zachodnią część Grecji Środkowej [40]:

Acarnania prior occurrit inter Epyrum Boeotiamque protensa, cui Aetholia vel coniuncta vel commixta esse videtur, haec hodie Ducatus appellatur.

Najpierw napotykamy Akarnanię, która rozciąga się między Epirem a Beocją. Akarnania sąsiaduje, czy też, jak się zdaje, tworzy jedną całość z Etolią, którą dzisiaj określa się mianem księstwa.

\footnotetext{
${ }^{32}$ Strabo 9, 1, 1-6.

${ }^{33}$ Plinius, Historia Naturalis 4, 23.

${ }^{34}$ Ptolemaeus, Geographike 3, 14, 1.

${ }^{35}$ Ptolemaeus, Geographike 3, 14, 36.
} 
Celem pracy autora jest przekazanie konkretnej wiedzy utrzymanej w kategoriach ściśle naukowych. Rezultat jest niewątpliwie świetny - czytelnik poznaje dokładnie, gdzie leży Akarnania i jaki jest jej stosunek do Etolii. Podana informacja pokazuje i rozstrzyga wszystko.

Trochę inaczej, niemniej w sposób znamienny postępuje autor przy prezentacji ostatniej greckiej krainy - Epiru. Pisarzowi przyświecała tu znowu ambicja wszechstronnego ukazania tego regionu Hellady, oświetlenia go na wszystkich możliwych płaszczyznach: geograficznej, historycznej, spojrzenia na niego oczami różnych antycznych autorów. Nie wartościując rezultatów tych wysiłków, stwierdzić trzeba, że spośród wszystkich omówień greckich krain relacja o Epirze jest najobszerniejsza [40]-[41]:

Epirus in occidua parte ab Acrocerauniis montibus incipit, protenditurque versus orientem usque ad Ambrachium sinum per stadia $\mathrm{M}$ et $\mathrm{CCC}^{36}$. Septentrionalem eius partem Ptolemaeus $^{37}$ Macedoniae coniungi tradit. Orientalem Achaiae usque ad ostia fluminis Acheloi, occidentale latus Ionico excipi pelago afferit. Strabo ${ }^{38}$ Ausoniam hoc idem mare appellavit. In Epiro quattuordecim fuisse gentes Theopompus ${ }^{39}$ tradidit, quarum celebratissimae Chaones et Molossi. Regnum enim quandoque tenuere prius Chaones, posterius Molossi, qui propter regum cognationem, ex Aeacidarum ${ }^{40}$ sanguine prognati mirum in modum amplificati fuerunt, penes quos Dodonae vetus oraculum ac nobile viguit. Oram eius terrae maritimam felicem atque uberem tradidere, multaeque olim urbes et oppida munitissima in Epyro fuere. Sed propter populorum rebelliones, quibus cum Romanis contenderunt, provincia vastata est, septuaginta enim Epyrotarum urbes a Paulo Aemilio imperatore funditus eversas esse, auctor est Polybius $^{41}$, victis Macedonibus et Perseo rege superato. (...) Apud Epyrum Actica pugna late memorabilis commissa est ${ }^{42}$, in qua Caesar Augustus Marcum Antonium navali proelio vicit, et simul Aegypti reginam Cleopatram (nam et ipsa huic certamini praesens interfuit). Ob quam rem victor Augustus in Ambrachio sinu urbem condidit, eique vocabulum indidit Nicopolim, id est victoriae civitatem. Ambrachii sinus ostium pauloquam stadia quattuor maius est, circuitus stadia CCC amplectitur, optima omni ex eius parte statio. Ingredientibus [41] occurrebant olim a dextra habitantes Graeci Acarnanes et Apollinis Actii ${ }^{43}$ templum quodam in tumulo ad ostium eminens. (...) Sinistra vero Nicopolis est et Epyrotarum Colonia Cassiope. Nostra aetas Epyrum Artam appellat. (...) In huius litore apud Acroceraunios montes finiri Adriae vel Adriatici maris navigationem et Ionium incipere pelagus Straboni ${ }^{44}$ visum est, apud quem mare Ausonium idem quod Ionium esse apparet, cum Epyri oram Ausonio ablui pelago affirmet.

Epir od zachodu zaczyna się pasmem górskim Akroceraunii, ciągnie się na odległość tysiąca trzystu stadiów ku wschodowi aż do Zatoki Ambrakijskiej. Ptolemeusz utrzymuje, że od strony północnej sąsiaduje z Macedonią, od wschodniej z Achają aż do ujścia rzeki Achelous,

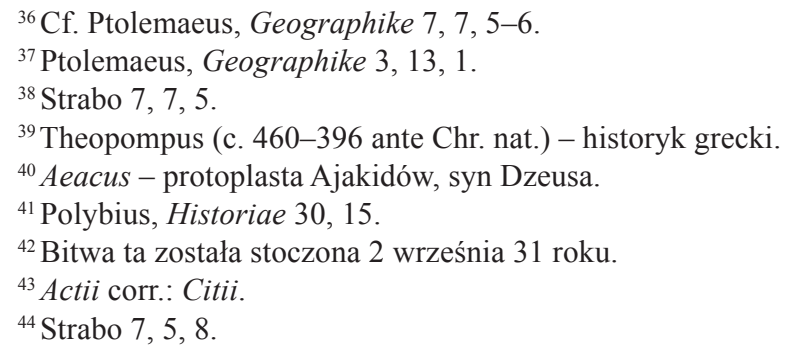


zachodnią granicę, według uczonego, ma stanowić Morze Jońskie. To morze Strabon nazywa Morzem Auzońskim. Zdaniem Theopompa, w Epirze żyje czternaście plemion, z których najsławniejsi są Chaonowie i Molossi. Niegdyś krainą tą władali Chaonowie, później Molossi, którzy mając królewskie pochodzenie, gdyż wywodzili się z krwi Ajakidów, urośli w potęgę. W czasie ich panowania wielkiego znaczenia nabrała Dodona - starożytna i sławna wyrocznia. Molossi przekształcili nadmorskie wybrzeża swego kraju w pas ziemi kwitnącej i szczęśliwej, w Epirze wznieśli także liczne miasta i osiedla. Lecz w trakcie buntów wznieconych przez inne plemiona i walk z Rzymianami, kraina ta została spustoszona. Wtedy to, jak podaje Polibiusz, siedemdziesiąt miast epirodzkich całkowicie zburzył wódz rzymski Emiliusz Paulus, który pokonał także Macedończyków i pobił króla Perseusza. (...). U wybrzeży Epiru pod Akcjum stoczona została bardzo sławna bitwa, w której - a było to starcie na morzu, cesarz August pokonał Marka Antoniusza, a także Kleopatrę - królową Egiptu, bo również i ona brała udział w tej bitwie. By upamiętnić to zwycięstwo, August zbudował nad Zatoką Ambrakijską miasto, któremu nadał nazwę Nikopolis, co znaczy miasto zwycięstwa. Ujście Zatoki Ambrakijskiej ma niecałe cztery stadia szerokości, jej obwód to 300 stadiów, każda część jej wybrzeża doskonale nadaje się do zacumowania. Oczom opuszczających Zatokę [41] niegdyś ukazywał się po prawej stronie kraj Akarneńczyków będących Grekami oraz świątynia Apollona akryjskiego, usytuowana nad Zatoką na pewnym wzgórzu. (...). Po lewej stronie leży Nikopolis i miasto Cassiope założone przez kolonistów epirodzkich. Nasz wiek określa Epir mianem Arty. (...). Według Strabona, na wybrzeżu epirodzkim u stóp Gór Akroceraunijskich kończą się szlaki żeglowne Morza Adryjskiego czyli Adriatyckiego, a zaczynają wody Morza Jońskiego. U tego autora okazuje się, że Morze Auzońskie jest tym samym akwenem, co Morze Jońskie, uczony twierdzi bowiem, że wybrzeże Epiru oblewa Morze Auzońskie.

I tu raz jeszcze mamy okazję spostrzec, jak motywy geograficzne i historyczne splatają się w relacji autora. Przykładem owych wątków „dziejowych”, wkraczających w sprawy stricte geograficzne jest m.in. wzmianka o bitwie pod Akcjum, stanowiącej jedno z najsławniejszych starć zbrojnych czasów antycznych. Metrykę pochodzenia tego zdarzenia ustalić nietrudno: zawędrowało tu prostą drogą, wiodącą od przekazów historyków starożytnych poprzez poezję epoki augustowskiej - jako motyw niezwykle popularny, zwiastujący początek nowej epoki określanej mianem złotego wieku. W tekście renesansowego pisarza pojawiło się nawet w otoczeniu dawnego zwycięskiego splendoru, którego wyrazem było założenie nowego miasta - Nikopolis. Ale funkcje, dla których zdarzenie w cytowanym ustępie przywołano, świadczą, że zmagania militarne między Oktawianem a Antoniuszem i Kleopatrą w świadomości ludzi europejskiego odrodzenia stały się już na dobre istotnym faktem dziejów kontynentu.

Podobnie motyw rzymskiego wodza Emiliusza Paulusa, zwycięzcy spod Pydny, zastosowany został jako niezawodny sposób zarówno charakterystyki miejsc bitewnych, jak i przypomnienia wielkości Rzymu. Tu motyw ten potrącony został typowo, w kontekście świadectw historyka Polibiusza - służy nie tylko przedstawieniu dziejowych wypadków, ale też jako dowód erudycji renesansowego dzieła. Polibiusz jest ważnym źródłem dla pisarza, staje się autorytetem, ekspertem w dziedzinie historii.

Wypowiedź Piccolominiego o Grecji wpisuje się doskonale w całe dzieło De Europa. Już na podstawie cytowanych fragmentów widać, że jest ono 
uporządkowane, przejrzyste, zawiera informacje wyrażone w sposób dość ciekawy, poszczególne uwagi włoskiego duchownego splatają się z ustaleniami antycznych pisarzy. Słowem - to praca na tle literatury naukowej XV wieku nowatorska, której wartość dostrzegło wielu innych ówczesnych twórców. Wartość dotyczyła także samego stylu - języka - rzecz bowiem oczywista, że w epoce ceniącej literaturę grecką i rzymską nie przechodzono obojętnie wobec estetyki słowa. Piccolomini odnosił się entuzjastycznie do Cycerona, którego nazywał największym mówcą (p. 136). Jeśli chodzi o praktykę literacką, odrzucił jednak metodę retoryczną polegającą na operowaniu stylem ozdobnym (genus grande), opowiadał się natomiast za stylem prostym i skromnym (genus tenue), pełniącym głównie funkcje informacyjne i pouczające ${ }^{45}$. Uznał zatem, że kwiecistość słów nie może przesłonić opisywanego przedmiotu. Byłoby to podejście nienaukowe, niehistoryczne, toteż nie lubował się w retorycznej inwencji. Skupiał się przede wszystkim na materiale, który miał do opracowania, na zagadnieniach i sprawach, jakimi się interesował. Ornament słowny schodził u niego na dalszy plan, liczyła się precyzja wysłowienia, istotną treść danej sprawy badał samą dla siebie, badał w zakresie meritum, nie zabiegając o ozdobność czy górnolotność. Nie trzeba chyba dodawać, że ta oszczędność stylistyczna była w tym wypadku zaletą. Styl lapidarny i zwięzły, a zarazem nigdy nie popadający w nudę i zmanierowanie, pasował idealnie do dysertacji naukowej.

Wobec tych wszystkich walorów dzieła Piccolominiego, Jan ze Stobnicy miał prawo uznać je za przydatne dla polskiego czytelnika tak ze względów merytorycznych, jak i językowych. Zabiegał bowiem o przedstawienie w Polsce nowoczesnego podręcznika geografii. W jego ramach uwzględnił dość obszerny fragment dotyczący Grecji, który stanowiąc bezpośrednią wypowiedź o tej krainie, reprodukował te wzorce i te kategorie mówienia o niej, jakie obowiązywały w Europie od czasów antycznych. Obraz Hellady był więc tu także sprawą swoistej edukacji. I pełnić mógł tę edukacyjna rolę tym bardziej, że w Polsce przełomu XV i XVI wieku nie łączył się on z jakąkolwiek wcześniejszą, nieantyczną próbą opisu Grecji; przeciwnie, Jan ze Stobnicy jako pierwszy wprowadzał na polski grunt rzetelne informacje geograficzne i historyczne o tej krainie, wprowadzał konteksty, w których ona występowała, czy nawet stawała się symbolem pewnych sytuacji. Tego rodzaju wiedza pełniła jednak nie tylko funkcje edukacyjne, ale i kształtowała postawy ludzkie. Bo opowieść o Grecji, w której dokonywały się wielkie dzieła, w której działały wielkie postaci, to było także zadanie dla odbiorcy. Nie tylko dla studenta Akademii Krakowskiej, którego obowiązkiem było zaliczenie przedmiotu ,geografia”. To zadanie dla każdego polskiego czytelnika czy słuchacza, który zapoznawszy się w wykładem Jana ze Stobnicy musiał zdać sobie sprawę, że w tym obrazie Hellady jest coś wspaniałego, coś z najistotniejszych przejawów kultury europejskiej.

\footnotetext{
${ }^{45}$ O stylu Piccolominiego vide Bisaha 2013: 38-41; Ojrzyński 2014: 24-27.
} 


\section{BIBLIOGRAFIA}

Teksty źródłowe

Jan ze Stobnicy, Introductio in Ptolemaei cosmographiam cum longitudinibus et latitudinibus regionum et civitatum celebriorum, ed. F. Ungler, Kraków 1512.

Jan ze Stobnicy, Introductio in Ptolemaei cosmographiam cum longitudinibus et latitudinibus regionum et civitatum celebriorum, ed. H. Wietor, Kraków 1517.

\section{Opracowania}

Barycz 1935: H. Barycz, Historia Uniwersytetu Jagiellońskiego w epoce humanizmu, Kraków 1935.

Barycz 1935: H. Barycz, Ślazacy na Uniwersytecie Jagiellońskim od XV-XVIII wieku, Katowice 1935.

Barycz 1948: H. Barycz, Śląacy w polskiej kulturze umystowej na tle polsko-ślaskich związów duchowych w przeszłości, w: Oblicze Ziem Odzyskanych. Dolny Ślask, t. II. Wrocław 1948, 499-562.

Bisaha 2013: N. Bisaha, Introduction, w: Aeneas Silvius Piccolomini, Europe (c. 1400-1458), translated by R. Brown, ed. N. Bisaha, Washington 2013.

Gniadek 1956: S. Gniadek, Traktat semantyczny Jana ze Stobnicy, w: „Sprawozdania Poznańskiego TPN" 1 (1956).

Buczek 1963: K. Buczek, Dzieje kartografii polskiej od XV do XVIII wieku: zarys analityczno syntetyczny, Wrocław 1963.

Iłowiecki 1982: M. Iłowiecki, Dzieje nauki polskiej, Warszawa 1981.

Knoll 2016: P.W. Knoll, „, A Pearl of Powerful Learning”. The University of Cracow in the Fifteenth Century, Leiden 2016.

Michalski 1913: K. Michalski, Jan ze Stobnicy jako przedstawiciel skotyzmu w Polsce, „Sprawozdania z Czynności i Posiedzeń AU” 18 (1913), 12-13.

Michalski 1915: K. Michalski, Michat z Bystrzykowa i Jan ze Stobnicy jako przedstawiciele skotyzmu w Polsce, „Archiwum Komisji Badania Historii Filozofii w Polsce”, t. I, część 1 (1915), 21-80.

Michałowska 1997: T. Michałowska, Średniowiecze, Warszawa 1997.

Ojrzyński 2014: R. Ojrzyński, Obraz Polski i Polaków w pismach Eneasza Sylwiusza Piccolominiego (papieża Piusa II), Warszawa 2014.

Palacz 1970: R. Palacz, Jan ze Stobnicy, w: „Materiały do Historii Filozofii Średniowiecznej w Polsce" 1 (1970), 23-38.

Rott 1995: D. Rott, Staropolskie chorografie, Katowice 1995.

Skubała-Tokarska 1983: Z. Skubała-Tokarska, Organizacja nauki w Polsce, w: Zarys dziejów nauk przyrodniczych $w$ Polsce, Warszawa 1983.

Staszewski 1966: J. Staszewski, Historia nauki o Ziemi w zarysie, Warszawa 1966.

Szelińska 1980: W. Szelińska, Chorografia Regni Poloniae Jana Długosza, Kraków 1980.

Szelińska 1984: W. Szelińska, Jan Dlugosz, storico o primo geografo polacco, Wrocław 1984.

Tarnowska 1962-1964: I. Tarnowska, Jan ze Stobnicy, w: Polski Stownik Biograficzny t. X, Wrocław 1962-1964; 480-481.

Wielgus 2005: S. Wielgus, Zachodnia i polska nauka średniowieczna - encyklopedycznie, Płock 2005.

Zawadzki 2013: R.K. Zawadzki, Wawrzyniec Korwin-życie i twórczość renesansowego humanisty, Częstochowa 2013. 


\section{THE LECTURE OF JAN OF STOBNICA (1470-1519) ON GREECE. INSPIRATIONS OF AENEAS SILVIUS PICCOLOMINI (1405-1464)}

\section{Sum mary}

Macedonia, Thessaly, Boeotia, Attica, the Peloponnese, the Isthmus, Achaea, Acarnania, Epirus - all of these famous Greek lands fascinated the Polish Renaissance scholar, Jan of Stobnica. He discussed them in his work Introductio in Ptolemaei cosmographiam cum longitudinibus et latitudinibus regionum et civitatum celebriorum which contained large parts of De Europa by Aeneas Silvius Piccolomini, an Italian scholar who became Pope Pius II in 1458. The article offers an account of the influence of this dissertation on Jan`s treatise, encompassing Greek geographical perspectives and within a broad range of historical events of ancient Greece. To illuminate these issues, the Polish Renaissance cultural context is discussed. This perspective shows the importance of Jan`s dissertation for the Polish culture. 